\section{p-ISSN 2476-9886 \\ e-ISSN 2477-0302

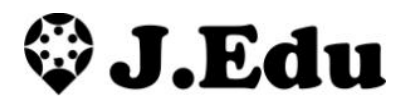

Volume 5 Nomor 1, 2019, HIm 54-59

\section{Jurnal EDUCATIO}

Jurnal Pendidikan Indonesia
Akses Online :

http://jurnal.iicet.org

Dipublikasikan oleh :

Indonesian Institute for Counseling, Education and Therapy (IICET)

Info Artikel:

Diterima: 06/08/2019

Direvisi: 06/13/2019

Dipublikasikan: 06/30/2019

\title{
Deviation Sexsual LGBT-Z: Preelemanary Research from Counseling Perspective
}

\author{
Alizamar Alizamar ${ }^{1}$ \\ ${ }^{1}$ Department of Guidance and Counseling, Universitas Negeri Padang
}

\begin{abstract}
The rise of coverage of LGBT-Z sexual deviations have led to a polemic in the midst of society. LGBT-Z sexual deviation if not intervened will have an impact on the health, education, social in the community. This condition is caused by various factors, including ignorance of parents, genetics, religion. This phenomenon tends to be even greater in millennial. This type of research is library research that focuses on LGBT-Z sexual deviation behavior. One professional who is considered capable as a solution to the problems that occur in the community is a counselor. Counselors can provide guidance and counseling services that focus on LGBT-Z sexual deviation behavior such as individual counseling, psychological approaches that are needed. It is hoped that the psychological assistance provided by individual counselors will be able to avoid LGBT-Z sexual deviation behavior.
\end{abstract}

Keywords: Counselor, Deviation Sexsual LGBT-Z.

This is an open access article distributed under the Creative Commons Attribution License, which permits unrestricted use,
distribution, and reproduction in any medium, provided the original work is properly cited. C2019 by author.

\section{INTRODUCTION}

Problems that are always discussed in communal life, including economic, political, educational and social problems. One of the most highlighted issues in various parts of the country is social issues (Biçmen \& Bekiroğulları, 2014; Daud, Salleh, Haridi, \& Ismail, 2016; Zulfa, 2019). This is seen by the changing patterns or forms of interactions in social relationships that result in social change (Bungin, 2013). One of the social changes happening now is the LGBT-Z deviation (lesbian, gay, bisexual, trans gender and adultery) (Anwar, 2017; Harahap, 2016; Lestari \& Sefitri, 2016; Rohmawati, 2016).

Lesbian is the sex orientation of women who just have the desire to have same-sex relations (Anwar, 2017; Meilaini \& Wulandari, 2018; Scott, Ritchie, Knopp, Rhoades, \& Markman, 2018; Yudiyanto, 2017). Second, Gay is the sex orientation of a man who only has the desire to have same-sex relationships (Men) (Asyari, 2017; Rivers \& Swank, 2017; Singh \& Shelton, 2011; Zuhri, 2016). Third, Bisexual is the sexual orientation of a man or woman who likes both types of men or women (Mahathanaya \& Lestari, 2017; Miranti \& Frieda, 2017; Sa, 2016), Fourth, Transgender is a sexual orientation of men or women by identifying or equating themselves with men or women (Budge, 2014; Chang \& Singh, 2016; Farmer \& Byrd, 2015; Galupo \& Resnick, 2016; Lestari, I, 
$\&$ Sefitri, 2016), Fifth Zina is coitus between a man or more with a woman or more without marital ties with the willingness of both parties (Ab Razak \& Hamjah, 2017; Harahap, 2015; Huda, 2015).

In the life of modern society, the phenomenon of Lesbian, Gay, Bisexual, Transgender and Adultery (LGBT-Z) is a case of familiar sexual orientation. According to a survey conducted by the PEW Research, Global Attitudes Project released on 4 June 2013 regarding acceptance of homosexual groups in the world, Indonesia ranks 7th out of 10 with a percentage of 3\% (Adelina, 2016; Sinaga \& Sinambela, 2013). While among all the countries that have the most Muslim population, Indonesia ranks 5th with 93\% of the 1000 respondents of Indonesian people expressing their negative attitude towards homosexuals. That is, homosexual problems are still contradictory for Indonesian people. The results of the 2016-2017 national survey on the number of LGBT in Indonesia with a sample of 1220 respondents in each survey, March 2016: 988 (81\%), September 2017: 1057 (87\%), December 2017: 1059 (87\%) (Saiful Mujani, 2018). From the above data, it is known that LGBT in Indonesia has increased every year.

Phenomena related to the issue of LGBT-Z sexual deviation behavior arise not only because of environmental influences, but LGBT-Z can also be formed due to conditions in the family (Bockting, W. O., Knudson, G., \& Goldberg, 2006; Prasetyo, 2015). A few researchers focused on results as well revealed that LGBT-Z occurred due to lack of knowledge and attitudes of their friends towards LGBT-Z and most LGBT-Z found it difficult to communicate and interact socially in the family, school (colleges) and in the community (Astuti, DA, \& Kurniati, 2018; Rokhmah, Nafikadini, Luthviatin, \& Istiaji, 2012). If LGBT-Z is not prevented, it will have many negative impacts, especially for the younger generation. The objectives of this research are to discuss LGBT-Z deviations from a counseling perspective so that counselors or psychologists can overcome LGBT-Z behavior in the community, and it is hoped that counselors can handle these problems well by involving the role of family or parents.

\section{METHOD}

This type of research is library research. The objectives of this research are series of studies relating to library data collection methods, or research whose research objects are explored through various library information (books or scientific journals) that discusses LGBT-Z behavior. Literature research is a study that critically examines the knowledge, ideas, or findings contained in the body of academic-oriented literature.

\section{RESULT AND DISCUSSION}

LGBT-Z is a term that develops in society (Dacholfany, 2017; Daud et al., 2016; Munajat, 2017; Rehman \& Polymenopoulou, 2013), whereas in psychiatry science known sexual orientation includes heterosexuals, homosexuals, bisexuals. LGBT-Z is a behavior that is very detrimental to the identity of the individual itself and damage the future. LGBT-Z is an abbreviation of Lesbian, Gay, Bisexual, Transgender and Adultery. Lesbian is a behavior of a woman who loves and likes women, for both physical and sexual and spiritual, Gay is a man who likes and loves men and this behavior is often referred to as homosexual, Bisexual people who can have emotional and sexual relations from two genders, and he can have a love affair with both men and women. Trans gender is the inequality of a person's gender identity with his gender, so it is possible to have gay, bisexual or heterosexual behavior (Pasilaputra, 2016; Saleh, G., \& Arif, 2017). In the Indonesian, Penal Code explained that the so-called adultery is as mentioned in article 284 of the Criminal Code as a criminal act with a prison sentence of up to 9 months, with the following conditions: 1). He is married to men who commit adultery. He is aware that article 27 of the Criminal Code, 2). A married woman who commits adultery. In the opinion of the Imams, the Imams understand adultery as follows: a) According to Safi'iyah, adultery is the act of a man inserting his penis into the vaginal opening of a woman who is not his wife or slave without doubt, b) According to Malikyah. Adultery is the act of a man holding other women who are not his wife in the vaginal opening or rectum, c) according to hanafiyah. Adultery is an affair between a man, and a woman in her vagina is not her slave and without her subject to him. From the various meanings above it can be said that LGBT-Z is a form of deviant behavior sexual seeking pleasure both psychologically and psychologically that deviates from norms and religion.

In the psychological view, LGBT-Z is divided into two parts, the first which accepts its sexual orientation and the second do not accept but are unable to overcome it so that it itself feels burdened (Zaini, 2017). According to Oetomo (2001) LGBT-Z in Indonesia is categorized as a mental illness which is summarized in the Guidelines for Mental Disorders Diagnostics (PPDGJ). However, in 1983 LGBT was excluded from PPDGJ 
so that LGBT behavior was no longer a mental illness but was a desire only owned by individuals in the form of sexual orientation.

According to Ahmina (2008) factors that cause LGBT behavior, are deviations are; 1) Family factor. Childhood experience or trauma. For example, based on his parents and child abuse, (Pasilaputra, 2016) 2) Association and the environment. Social habits and the environment are the biggest factors contributing to this sexual disorder in which one family member does not show affection and the attitude of parents who feel the explanation about sex is a taboo, 3) Biological. A homosexual has a tendency to do homosexuality because he gets a push from the body that is hereditary / genetic and this can be treated morally and religiously, 4) Moral and moral factors. Sexual deviations occur because of a shift in moral norms adopted by the community and the depletion of social control that exists in the community, 5) Weak religious knowledge. Little and weak religious knowledge is an opportunity for someone to do LGBT. LGBT views in the Religious Perspective say LGBT is not merely a matter of sexual orientation, but also a deviation of social behavior (Saleh, G., \& Arif, 2017). This is done solely looking for pleasure both physically and psychologically by connecting with the same sex.

Several factors that cause a person to behave in LGBT are explained through Erikson's Psychosocial theory, namely Biological Theory (Genetic Factors and Hormonal Factors) and Psychosocial Theories (Parenting, Life Trauma, Psychological Signs, and First Sex Experience) (Soetjingsih, 2004). So it can be said that LGBT is sexual behavior that deviates from the actual sexual role $t$ causes sexual function to change or there is a malfunction in someone using their sexual organs.

\section{Lifestyle of an LGBT-Z}

Lifestyle is a picture for someone who does it and it can illustrate how moral someone in his life in society (Kaparang, 2013). Lifestyle is an overall picture of a person's thoughts about how he makes choices and about how someone uses their time and money in life (Herlyana, 2014). Meanwhile, according to Sakinah, (2002) lifestyle is an overall picture of a person in carrying out his life in interacting with his environment. The current of increasingly rapid globalization brings all people to be able to play an active role in life if they do not want to sink and be left behind. Sometimes in fulfilling a person's lifestyle, they are willing to leave the norms that exist in their country. Lifestyle can create a new color in a person's life by increasing creativity. Hidayat, T., Bakar, A., \& Bustamam, (2017) suggested that at this time many teenagers were abusing lifestyle. Teenagers sometimes just follow their passions and pleasures, causing social deviations in life. Teenagers tend to imitate the current lifestyle that comes from western culture so that it can plunge someone into sexual behavior deviations. This happens because of mindset errors (Hikmat, 2015). The wrong mindset can deduce itself what is happening around without looking for the truth of what is seen and known and tends to be unconscious with the limits of knowledge. Some LGBT-Z actors think that sexual deviation is a culture that can be accepted by the community (Kiki Megasari Yulrina Ardhiyanti, 2017). Whereas people, especially in Indonesia, strongly reject LGBT-Z deviant behavior because it violates existing norms and there is no religion that justifies LGBTZ behavior (Ayuni \& Sham, 2019; Hanum, 2015; Saleh, G., \& Arif, 2017).

\section{Psychological impact for LGBT-Z}

A psychiatrist argues that LGBT-Z is a mental illness and can be transmitted to others (Harahap, 2016), and refutes the opinion of some people who say that LGBT-Z is normal and natural behavior so it is not a disease. This transmission can occur in the environment and peers (Diniati, 2018; Vitasandy \& Zulkaida, 2011). An individual will not know about LGBT-Z if it is not taught or exemplified by others (Yudhiyanto, 2017). The negative impact of LGBT-Z does not only affect one's health and personality, but also adversely affects harmony in the family and community environment (Saleh, G., \& Arif, 2017). Further stated in the aspect of sociology, LGBT-Z can cause an increase in social symptoms, and disability rates become high and difficult to overcome. In the psychological aspect, the habits of LGBT-Z behavior can have a bad influence on the psyche and have a very strong effect on the nerves so that the brain will digest that this bad habit is a natural thing. The perpetrator can think that he is not a real man or woman and is confused by the state of his own identity. This will also have an impact on one's mind because they feel comfortable with similar individuals and cause the offender to become moody.

\section{The role of the counselor}

Counselor is someone who has expertise in the field of counseling services and has completed a counselor education program in a professional. In the Minister of National Education Regulation, No.27 year (2008) concerning Academic Competency Qualification Standards for Counselors (SKAKK) states that professional competency includes: (1) deeply understanding the counselee being served, (2) mastering the theoretical 
foundation and framework of guidance and counseling, (3) provide guidance and counseling services that are independent, and (4) develop personal and professional counselors on an ongoing basis. According to Prayitno \& Amti, (2004) counselor goals are: 1). To help individuals make choices, adjustments and interpretations in relation to certain situations, 2). To strengthen educational functions, and 3). To help people become useful people, not just follow useful activities. When exploring clients, it is important for the counselor to identify which type of homosexual is being experienced by the client, this is done because, how to handle each type of homosexual is different. With the identification of homosexual types can facilitate counselors in providing assistance to clients. A counselor in handling client problems related to LGBT-Z behavior in advance, the counselor can help clients to be able to accept themselves and can socialize the social environment so as to avoid risky behaviors (ansyah Ardiansyah, 2018; Dacholfany, 2017; Lestari, I., \& Sefitri 2016).

The dynamics experienced by LGBT-Z, as a group that is prioritized and considered deviant, is very likely to be faced by counselors. The meaning of sexuality and LGBT-Z identity by counselors is influenced by several factors, such as attitudes, values, beliefs, gender roles, religion, cultural assimilation, and community support (Fitri, 2017). This requires professional counselors in dealing with clients related to LGBT-Z. Some experts also suggest that in dealing with clients the counselor must first do the following: 1) Identification 2) Exploration, 3) Seeing how far he understands himself and his situation, at this stage the client is assisted by the counselor to see himself from various perspectives, 4) organize irrational beliefs because basically changes in gender are justifications of irrational beliefs, 5) Comparison of Identity that occurs through comprehensive selfexploration and comparing himself with the community, parents, peers and others, at this stage the counselor provides reinforcement about what is he has done, so clients find new understanding and comfort in running a new life (Alessi, Dillon, \& Kim, 2016; Beck, Rausch, Wikoff, \& Gallo, 2018; Lestari \& Sefitri, 2016; McCarn \& Fassinger, 1996)

So the role of the counselor in handling LGBT-Z behavior certainly starts with distancing the counselors from negative thoughts towards the client, this is necessary, because LGBT-Z has been rejected by the social environment so that the positive behavior given by the counselor to the client is the first approach to explore events or experiences from clients and help clients get out of LGBT-Z sexual deviation behavior. After this, the counselor seeks to condition the client to change the deviation that is done and the extent to which the achievement of the deviation changes the client has planned.

\section{CONCLUSION}

The LGBT-Z has denied its nature as a human being, because it performs behavior that is clearly prohibited and violates its nature as a human being. One of the preventive measures for handling LGBT-Z deviation behavior through a counselor. The counselor can do help to prevent LGBT-Z behavior that must be done by the counselor first, namely: 1) Identification 2) Exploration, 3) Seeing how far he understands himself and his situation, at this stage the client is assisted by the counselor to see himself from various perspectives, because they have been rejected enough by their social environment so that positive behavior given by counselors towards clients is the first approach to explore events or experiences from clients and help clients get out of LGBT-Z sexual deviation behavior, 4) organize irrational beliefs because basically change in their gender is a justification of his irrational beliefs, 5) Comparison of identity that occurs through self-exploration as a whole and comparing himself with the community, parents, peers and others, after this counselor seeks to condition the client to change the deviation is done and the extent to which the $\mathrm{p}$ achieve changes in planned client behavior deviations.

\section{REFERENCES}

Ab Razak, M. R., \& Hamjah, S. H. (2017). Faktor Zina dan Kesannya dalam Kehidupan Remaja. Jurnal Sains Insani, 2(2), 1-9.

Adelina, S. (2016). Peran Pekerja Sosial dalam Pembentukan Konsep Diri Positif Bagi Lesbian Di Kota Tasik. Prosiding Penelitian Dan Pengabdian Kepada Masyarakat, 3(2).

Ahmina, A. (2008). Islam dan Homoseksual. Jakarta: Pusta Zahra.

Alessi, E. J., Dillon, F. R., \& Kim, H. M.-S. (2016). Therapist correlates of attitudes toward sexual minority individuals, affirmative counseling self-efficacy, and beliefs about affirmative practice. Psychotherapy Research, 26(4), 446-458.

Ansyah Ardiansyah, A. (2018). Upaya bimbingan konseling nilai dan spiritual terhadap Transgender di Yogyakarta. Counsellia: Jurnal Bimbingan Dan Konseling, 8(2), 71-87. 
Anwar, F. (2017). Perubahan dan permasalahan media sosial. Jurnal Muara Ilmu Sosial, Humaniora, Dan Seni, 1(1).

Astuti, D. A., \& Kurniati, N. (2018). Factors Influencing Stigma to Lesbian, Gay, Bisexual, and Transgender (LGBT) Among Teenagers at Ngaran Village, Gamping, Sleman, Indonesia. Global Health Management Journal, 2(2), 19-24.

Asyari, F. (2017). LGBT dan Hukum Positif Indonesia. Jurnal legalitas, 2(1), 57-65.

Ayuni, Q., \& Syam, H. M. (2019). Proses Gatekeeping Pemberitaan LGBT Pada Harian Serambi Indonesia. Jurnal Ilmiah Mahasiswa Fakultas Ilmu Sosial \& Ilmu Politik, 4(2).

Beck, M. J., Rausch, M. A., Wikoff, H. D., \& Gallo, L. L. (2018). Ecological considerations and school counselor advocacy with LGBT students. Journal of Counselor Leadership and Advocacy, 5(1), 45-55.

Biçmen, Z., \& Bekiroğ ulları, Z. (2014). Social problems of LGBT people in Turkey. Procedia-Social and Behavioral Sciences, 113, 224-233.

Bockting, W. O., Knudson, G., \& Goldberg, j. M. (2006). Counseling and mental health care for transgender adults and loved ones. International Journal of Transgenderism, $9^{\prime}(3-4), 35-82$.

Budge, S. L. (2014). Navigating the balance between positivity and minority stress for LGBTQ clients who are coming out. Psychology of Sexual Orientation and Gender Diversity, 1(4), 350-352. https://doi.org/10.1037/sgd0000077

Bungin, B. (2013). Sosiologi Komunikasi: Teori, Paradigma, dan Diskursus Teknologi Komunikasi di Masyarakat. Jakarta: Kencana Prenada Media Group.

Chang, S. C., \& Singh, A. A. (2016). Affirming psychological practice with transgender and gender nonconforming people of color. Psychology of Sexual Orientation and Gender Diversity, 3(2), 140-147. https://doi.org/10.1037/sgd0000153

Dacholfany, M. I. (2017). Dampak LGBT DAN Antisipasinya di Masyarakat. Nizham Journal of Islamic Studies, 4(1), 106-118.

Daud, Z., Salleh, N. M., Haridi, N. M., \& Ismail, A. M. (2016). Sikap Belia Terhadap Pemikiran Tidak Beragama. Al-Irsyad: Journal of Islamic and Contemporary Issues, 1-12.

Diniati, A. (2018). Konstruksi Sosial Melalui Komunikasi Intrapribadi Mahasiswa Gay di Kota Bandung. Jurnal Kajian Komunikasi, 6(2), 147-159.

Farmer, L. B., \& Byrd, R. (2015). Genderism in the LGBTQQIA Community: An Interpretative Phenomenological Analysis. Journal of LGBT Issues in Counseling, 9(4), 288-310. https://doi.org/10.1080/15538605.2015.1103679

Galupo, M. P., \& Resnick, C. A. (2016). Experiences of LGBT Microaggressions in the Workplace: Implications for Policy. Sexual Orientation and Transgender Issues in Organizations: Global Perspectives on LGBT Workforce Diversity, 1(1), 271-287. https://doi.org/10.1007/978-3-319-29623-4

Hanum, F. (2015). Status Anak Yang Dilahirkan Dari Perkawinan Wanita Hamil Karena Zina Menurut Kompilasi Hukum Islam Dan Undang-Undang Nomor 1 Tahun 1974 Tentang Perkawinan. PREMISE LAW JURNAL, 8.

Harahap. (2016). LGBT di Indonesia: Perspektif Hukum Islam, HAM, Psikologi dan Pendekatan Maș lah ah. Al-Ahkam, 26(2), 223-248.

Harahap, Z. A. A. (2015). Reformulasi tindak Pidana Zina dalam RUU KUHP Indonesia dan Sumbangan Hukum Islam Terhadapnya. Yurisprudentia: Jurnal Hukum Ekonomi, 1(1), 16-27.

Herlyana, E. (2014). Fenomena Coffe Shop Sebagai Gejala Gaya Hidup Baru Kaum Muda. THAQAFIYYAT: Jurnal Bahasa, Peradaban Dan Informasi Islam, 13(1), 187-204.

Hidayat, T., Bakar, A., \& Bustamam, N. (2017). Gaya Hidup LGBT di Tengah Masyarakat Kota Banda Aceh. Jurnal Ilmiah Mahasiswa Bimbingan \& Konseling, 2(2).

Hikmat, M. (2015). Awas Perilaku Menyimpang Waspadalah. Bandung: Gafitri Bandung.

Huda, S. (2015). Zina dalam Perspektif Hukum Islam dan Kitab Undang Undang Hukum Pidana. HUNAFA: Jurnal Studia Islamika, 12(2), 377-397.

Kaparang, O. M. (2013). Analisa Gaya Hidup Remaja dalam Mengimitasi Budaya Pop Korea Melalui Televisi. Jurnal Acta Diurna, 2(2).

Kiki Megasari Yulrina Ardhiyanti, S. (2017). Fenomena Perilaku Penyimpangan Seksual Oleh Lesbian, Gay, Biseksual, dan Transgender (LGBT) di Kota Pekanbaru. Menara Ilmu, (11), 78.

Lestari, I., \& Sefitri, S. (2016). Konseling Bagi Populasi Transgender. Jurnal Konseling Gusjigang, 2(1).

Lestari, I., \& Sefitri, S. (2016). Konseling Bagi Populasi Transgender. Jurnal Konseling Gusjigang, 2(1).

Mahathanaya, S. P., \& Lestari, M. D. (2017). Proses Pemilihan Pasangan Pada Wanita Biseksual. Jurnal Psikologi Udayana, 4(2), 249-261. 
McCarn, S. R., \& Fassinger, R. E. (1996). Revisioning sexual minority identity formation: A new model of lesbian identity and its implications for counseling and research. The Counseling Psychologist, 24(3), 508-534

Meilaini, E. R., \& Wulandari, D. A. (2018). Studi Kasus tentang Proses Pengambilan Keputusan Menjadi Lesbi. PSYCHO IDEA, 16(2), 75-87.

Miranti, W. T., \& Frieda, N. R. H. (2017). Identitas Diri Wanita Biseksual: Studi Fenomenologis pada Wanita Dewasa Awal. Empati, 5(1), 167-171.

Munajat, M. (2017). LGBT Perspektif Hukum Pidana Islam. Jurnal Cakrawala Hukum, 11(1).

Oetomo, D. (2001). Memberi Suara Pada Yang Bisu. Yogyakarta: Galang Press.

Pasilaputra, D. (2016). Pendekatan Psychotherapy Agama Dalam Menanggulangi Perilaku Menyimpang (LGBT). Journal Educative: Journal of Educational Studies, 1(2), 96-109.

Prasetyo, S. (2015). Pandangan Pekerja Terhadap Lesbian, Gay, Biseksual dan Transgender (LGBT) Di Jabodetabek: Study Kualitatif.

Prayitno, \& Amti, E. (2004). Dasar-dasar Bimbingan dan Konseling. Jakarta: Rineka Cipta.

Rehman, J., \& Polymenopoulou, E. (2013). Is green a part of the rainbow: sharia, homosexuality, and LGBT rights in the Muslim world. Fordham Int'l LJ, 37, 1.

Rivers, B., \& Swank, J. M. (2017). LGBT Ally Training and Counselor Competency: A Mixed-Methods Study. Journal of LGBT Issues in Counseling, 11(1), $18-35$. https://doi.org/10.1080/15538605.2017.1273162

Rohmawati, R. (2016). Perkawinan lesbian, gay, biseksual dan transgender/transeksual (lgbt) perspektif hukum islam. Ahkam: Jurnal Hukum Islam, 4(2), 305-326.

Rokhmah, D., Nafikadini, I., Luthviatin, N., \& Istiaji, E. (2012). Proses Sosialisasi Laki-laki Suka Seks dengan Laki-laki (LSL) pada Kalangan Remaja di Kabupaten Jember. IKESMA, 8(2).

Sa, M. (2016). LGBT dalam Perspektif Agama dan HAM. Nizham Journal of Islamic Studies, 4(1), 16-25.

Saiful Mujani. (2018). Kontroversi Publik Tentang LGBT di Indonesia Hasil Survei Nasional SMRC 2016-2017. Retrieved from https://www.slideshare.net/saidimanahmad/rilis-survei-smrcpandangan-publik-nasional-tentang-lgbt-20162017

Sakinah. (2002). Media Muslim Muda. Sol: Alfata.

Saleh, G., \& Arif, M. (2017). Rekayasa Sosial dalam Fenomena Save LGBT. Jurnal Komunikasi Global, 6(2), 148-163.

Scott, S. B., Ritchie, L., Knopp, K., Rhoades, G. K., \& Markman, H. J. (2018). Sexuality within female same-gender couples: Definitions of sex, sexual frequency norms, and factors associated with sexual satisfaction. Archives of Sexual Behavior, 47(3), 681-692.

Sinaga, T., \& Sinambela, M. (2013). Pengaruh stres kerja terhadap motivasi dan kinerja auditor pada kantor akuntan publik di kota Medan. Universitas Tarumanagara Journal of Accounting, 17(1).

Singh, A., \& Shelton, K. (2011). A content analysis of LGBTQ qualitative research in counseling: A tenyear review. Journal of Counseling and Development, 89(2), 217-226. https://doi.org/10.1002/j.15566678.2011.tb00080.x

Soetjingsih. (2004). Tumbuh Kembang Remaja dan Permasalahannya. Jakarta: Sagung Seto.

Vitasandy, T. D., \& Zulkaida, A. (2011). Konsep diri pria biseksual. Jurnal Ilmiah Psikologi, 3(2).

Yudhiyanto, Y. (2017). Fenomena Lesbian, Gay, Biseksual, dan Transgender (LGBT) di Indonesia Serta Upaya Pencegahannya. Nizham Journal of Islamic Studies, 4(1), 62-74.

Yudiyanto, Y. (2017). Dr. Yudiyanto, M. Si.-Fenomena Lesbian, Gay, Biseksual dan Transgender (Lgbt) Di Indonesia Serta Upaya Pencegahannya. Nizham Journal of Islamic Studies, 4(1), 62-74.

Zaini, H. (2017). LGBT dalam Perspektif Hukum Islam. JURIS (Jurnal Ilmiah Syariah), 15(1), 65-74.

Zuhri, M. A. (2016). Perkawinan Sejenis dalam Kajian Islam. Al-Ahwal: Jurnal Hukum Keluarga Islam, 8(1), 87-96.

Zulfa, Z. (2019). Contextual Learning of Character Values in Minangkabau Culture Course to Strengthen National Identity. Journal of Moral and Civic Education, 3(1), 38-47. 